\title{
An Empirical Study on the Effects of Using Kahoot as a Game-Based Learning Tool on EFL Learners' Vocabulary Recall and Retention
}

\author{
Alim Al Ayub Ahmed $\mathbb{D}^{1},{ }^{1}$ Biju Theruvil Sayed $\mathbb{D}^{2},{ }^{2}$ Ismail Suardi Wekke $\mathbb{D}^{3},{ }^{3}$ \\ Mulyanto Widodo $\left(\mathbb{D},{ }^{4}\right.$ Dian Rostikawati $(\mathbb{D}),{ }^{5,6}$ Muneam Hussein Ali $(\mathbb{D}),{ }^{7}$ \\ Hamed Ali Abdul Hussein $\mathbb{D}^{8},{ }^{8}$ and Mahdieh Azizian $\mathbb{D}^{9,10}$ \\ ${ }^{1}$ School of Accounting, Jiujiang University, Qianjin Donglu, Jiujiang 551, Jiangxi, China \\ ${ }^{2}$ Department of Computer Science, Dhofar University, PO Box 2509, PCode 211, Salalah, Oman \\ ${ }^{3}$ Graduate Program Institute Agama Islam Negeri (IAIN) Sorong, Sorong, Indonesia \\ ${ }^{4}$ Universitas Lampung, Bandar Lampung, Indonesia \\ ${ }^{5}$ Universitas Pamulang, Tangerang Selatan, Banten, Indonesia \\ ${ }^{6}$ Program Doktor Ilmu Manajemen, Program Pascasarjana, Universitas Pasundan, Bandung, Indonesia \\ ${ }^{7}$ Al-Nisour University College, Baghdad, Iraq \\ ${ }^{8}$ College of Physical Education and Sport Science, Al-Ayen University, Thi-Qar, Iraq \\ ${ }^{9}$ Modeling in Health Research Center, Institute for Futures Studies in Health, Kerman University of Medical Sciences, \\ Kerman, Iran \\ ${ }^{10}$ Department of General Education, Afzalipour Faculty of Medicine, Kerman University of Medical Sciences, Kerman, Iran
}

Correspondence should be addressed to Mahdieh Azizian; m_azizian@kmu.ac.ir

Received 31 January 2022; Revised 6 February 2022; Accepted 9 February 2022; Published 27 February 2022

Academic Editor: Ehsan Namaziandost

Copyright (C) 2022 Alim Al Ayub Ahmed et al. This is an open access article distributed under the Creative Commons Attribution License, which permits unrestricted use, distribution, and reproduction in any medium, provided the original work is properly cited.

Incorporating games into learning a foreign language is an effective strategy that can lower students' stress and improve their learning. Thus, this study tried to examine the impacts of Kahoot as a game-based learning tool on Iranian EFL learners' vocabulary recall and retention. To this end, 50 Iranian intermediate learners were chosen for the participants of the study. After that, the participants were randomly assigned to two equal groups, one experimental and one control. Then, the participants' English vocabulary knowledge was measured by administering a vocabulary pretest. After pretesting process, the participants in both groups received the treatment in two different ways. In the EG, the new vocabulary items were taught using the Kahoot game, while in the CG, the new ones were taught using traditional instruction. After finishing the treatment course, which lasted ten sessions, the two groups took the immediate vocabulary posttest. After three weeks, a delayed vocabulary posttest was administered to both groups to determine the effects of Kahoot on their vocabulary retention. The results of paired samples and independent samples $t$-tests depicted that there were significant differences between the immediate and delayed posttests of the EG and the CG in favor of the EG. The implications of this study can tell the teachers that teaching through game-based learning tools may produce better results than teaching through traditional methods. Also, the implications of this study can encourage students to practice and learn English even outside of the class context.

\section{Introduction}

Technology has infiltrated almost every aspect of our lives in our digital age. Indeed, technology has revolutionized the way our world operates and progresses. Technology has brought about significant changes in our private life, the economic globe, and other sectors throughout the entire planet [1]. It is remarkable to realize how the incorporation of technology into each aspect of human life and surroundings has had a significant influence on boosting 
efficiency and increasing productivity and quality in the job we perform. There is a minor question of whether incorporating technology into our educational system is transforming the educational landscape $[2,3]$. The incorporation of technology into our training has undoubtedly resulted in a plethora of novel learning methodologies and techniques that improve the overall efficiency and productivity of the educational process. Aside from giving learners a significant advantage and benefit, the development of new technology systems and software has provided instructors with the resources they require to boost participants' commitment to the teaching and learning process $[4,5]$.

With the advancement of technology, one subset of technology is educational games, which have a crucial role in language learning nowadays. According to Hadfield [6], classroom gamification is "an exercise with regulations, an objective, and a component of enjoyment" (p. 101). They allow students to actively participate in activities while also strengthening emotional responses such as curiosity, enthusiasm, and readiness to partake. In addition, games often emphasize the interpersonal and pragmatic components of language $[7,8]$. They have a beneficial impact on active involvement, allow for individualism and competitiveness in learning, and enable the opportunity to employ language abilities in a variety of contexts [9]. They can be incorporated in classroom activities to provide a funny yet challenging atmosphere and are especially useful to alleviate students' overwhelmed assignments and teachers' monotonous pedagogy.

As a result, as compared to conventional techniques, game-based learning provides an efficient language learning environment for learners. Online gamification lessens students' introversion. It allures risk-taking, praises students for their efforts in active participation, contributes to students' self-confidence, invites students to take the initiative and diagnose their background knowledge, encourages students to ask questions, helps students to develop their awareness, and corrects their mistakes $[10,11]$. Game-based learning has a crucial role in provoking students' enthusiasm for learning, improving the proper cognitive needs, and developing their individual socialization as well as healthy mental and physical development [12].

Kahoot is a game-based learning platform utilized in schools and colleges as an educational resource. The Kahoot platform results from the Lecture Quiz research project started at the Norwegian University of Science and Technology in 2006, where multiple prototypes were enhanced and assessed via experiments over several years [13]. In fall 2012, a start-up company was founded to improve a new game-based learning platform from the ground up named Kahoot! based on Lecture Quiz. The Kahoot! game-based learning platform was released in September 2013 [14]. Kahoot includes multiple-choice quizzes and jumbles that permit signing up and may be accessible using a web browser. Kahoot can be utilized to investigate students' knowledge and track their responses and scores for formative assessment $[15,16]$. Kahoot also includes trivia questions, and it is intended for interactive learning, with participants brought together around a shared screen such as an interactive whiteboard, projector, computer monitor, or a smart TV.

Screen-sharing solutions such as Kahoot, Skype, WhatsApp, and Google Hangouts may also be utilized with Kahoot. The game is designed so that players must regularly look up their gadgets. The gaming is straightforward; all participants join via a randomly generated game PIN displayed on a shared screen and use a tool to respond to questions given by an instructor, company leader, or other individuals [17]. The answers to these questions may be altered to grant credits. Following each question, points are added to the leaderboard. Kahoot also allows users to create questionnaires and provides a conversation platform.

Kahoot assists teachers in creating online exams from a succession of multiple-choice questions and mangles, as well as the addition of multimodal devices (films, photos, infographics, and so on.) to the questions to increase participation $[18,19]$. By using Kahoot, teachers can attract the student's attention to focus on the lesson and increase their task behavior. Most students prefer attractive games rather than paper-pencil activities.

By using Kahoot, we can develop EFL learners' vocabulary knowledge. Vocabulary learning is considered an essential part of foreign language learning [20]. Learning vocabulary necessitates students' competence in both theory and practice. Schmitt [21] states that studying vocabulary is crucial since language success is an essential measure. Similarly, mastering a foreign language is fundamentally linked to vocabulary development; a dearth of lexical items will impede the process of learning a foreign language. L2 learners may not attain desirable language learning results if they lack adequate vocabulary knowledge [22, 23]. According to Adam [24], English language learners' real communication is hampered by a lack of vocabulary knowledge. As a result, it is plausible that EFL learners demand proper vocabulary knowledge.

This study aimed to develop Iranian EFL learners' English vocabulary knowledge by using Kahoot as a kind of game-based learning platform. This study is significant since it worked on a new topic, and its results can encourage teachers and students to apply game-based instruction in language learning. In vocabulary learning, using games can give students the context of actual usage of the words. By using games, learners can practice both inside and outside the classroom. Also, teachers can keep students engaged in learning by using game-based learning.

\section{Review of the Literature}

While games have long been utilized in educational settings, gamification is a relatively new notion. Gamification uses game-like mechanisms (such as points, leaderboards, and badges) in nongame environments [25]. Meta-centered activities, incentives, and advancement are among the significant aspects of gamification, according to Dickey [26]. Furthermore, the gamification process should be considered. The interface design patterns and mechanics, design principles, game models, and game design patterns and game design approaches were proposed by Deterding et al. [27]. 
The theory of motivation, engagement, and psychology has investigated and described the advantages of gamification. The self-determination theory (SDT) [28] is the most often grounded theory connected to gamification. It discusses both extrinsic and intrinsic motivation. According to Muntean [29], gamification encourages intrinsic motivation by providing a feeling of dominance, independence, and connectivity via the usage of external features such as levels, points, and badges.

Plass et al. [30] argued that different motivational, cognitive, affective, and sociocultural theories, including social cognitive theory [31], achievement goal theory [32], activity theory [33], and situated learning theory [34], provide the foundation for the successful design of gamebased learning.

Games are fantastic teaching tools that may be utilized in any course to capture students' interest, increase engagement, and review subject material [35]. On the other hand, game-based response systems enable students to answer questions shown on a screen in class. The students use mobile devices, usually phones, to click their responses on multiple-choice questions. The answers to the questions are instantly shown graphically to the class. Learners have displayed the results in histograms, and the teacher may discuss or rehash the subject matter [36].

A new game-based response system on the web that is used both in online education and face-to-face learning contexts is Kahoot. The popular game-based response system Kahoot promotes the learners' curiosity and engagement, and this helps the instructors to discover areas of weaknesses in subject matter understanding and course design $[1,37]$. The incredibly competitive, involving, and enjoyable environment in Kahoot is very precious for learning purposes and psychological goals [1].

Kahoot has two modes, classic and team modes. Classically, learners play against learners. However, in team mode, the instructors can separate the class or learners into sections, and each team can collaborate in itself on a phone, tablet, or laptop and compete against other groups in a game-based setting while the instructor supervises the results [38]. Kahoot allows the instructors to form multiplechoice questions and show the correct answers. Kahoot can be opened on the web, and classes can play against each other or within each other. During the game, the learners compete for points. The learners require a code that the instructor issues to enter the game.

Like many tools, there are benefits and risks associated with Kahoot. The following points can be ordered concerning benefits: first of all, the technological tool is userfriendly. The learners can use the application without any downloads or computer knowledge; this helps them accustom to the learning environment. However, the instructor can assess the online learners' knowledge before they begin the course. According to results, the instructor can plan for teaching style and level [39].

Moreover, the tool is an excellent way to do a warm-up activity. This helps the instructors to begin with a play to remove the psychological barriers before the course starts. Besides, during the online course, the instructor can receive on- time feedback, and in the same way, the learners can assess their understanding as well. Moreover, the tool helps the instructor gamify the course and motivate the learners. However, it is a perfect tool for doing reviews at the end of the course. Lastly, the device will support interaction, which is very important in online learning, among the learning community [40].

To learn a language more straightforward, we should have a specific strategy. Students have to use various techniques to succeed in their learning process [41]. Games are employed as a strategy to engage pupils in their learning. Well-chosen and planned games are crucial because they provide students with a respite while also allowing them to practice language skills. Huyen [42] notes the following benefits of utilizing games to acquire vocabulary in the classroom: (a) games offer relaxation and enjoyment, allowing students to recall words more readily. (b) Because games feature friendly competition, they engage and motivate the students. (c) Vocabulary games provide real-world context into the classroom. Competition, collaborative play, and role-play are the benefits of games that involve learners both emotionally and cognitively [43]. According to Barbosa and de 'Avila Rodrigues [44], the advantages of game-based learning are activating and motivating learners and challenging them to learn by practicing.

According to Drake [45], active learning in school has some advantages for conceptual growth but only to the degree that it supports meaningful learning. Active learning strategies should be seen as part of a toolkit that may aid in material mastering, but only when applied correctly. Another benefit of teaching vocabulary via games is that games motivate learners because most learners do not like to memorize techniques because it is monotonous, but a game is enjoyable, and students get a break from the typical pattern of vocabulary sessions [46]. Teaching vocabulary using games can obtain valuable benefits because we learn knowledge and have fun with the learning media.

Some researchers proved the effects of Kahoot on language skills and subskills. Boulaid and Moubtassime [17] investigated the impact of Kahoot in improving the English vocabulary of Moroccan EFL University students. In their third semester at Sidi Mohamed Ben Abdellah University in Meknes, ninetyseven Moroccan English students were attacked. The purpose of this quasiexperimental research is to investigate the significance of introducing Kahoot as a Web 3.0 App within the classroom to increase college students' vocabulary, which adds to refining language abilities, mainly writing and speaking. Thus, the project exposes the degree to which Kahoot enables students to learn the word in context. The learners were educated via Kahoot exercises over eight weeks. Analyses of questionnaire answers before and after Kahoot exposure, presented to a suitable sample, demonstrate that it dramatically adds to students' vocabulary richness. Indeed, the study seeks an alternative teaching technique that would aid students in broadening their English vocabulary via online gaming. Faculty members may be able to develop new pedagogies due to the findings of this article. The final results suggest that Kahoot adds to the vocabulary enrichment of EFL learners.

Putri [47] analyzed the effect of the Kahoot game on increasing students' language understanding. This was a 
quasiexperimental research utilizing quantitative data as the data collection tool. The nonequivalent group design with pretest and posttest was used as the study design. This research focused on 7th learners at SMP Negeri 15 Semarang during the 2019-2020 academic year. The investigator used pretest, interventions, and posttest to collect data. The Kahoot game was used to educate the students in the EG during the treatment activity. The children in the CG, on the other hand, were instructed using the traditional technique. This study's tool is a multiple-choice vocabulary comprehension exam. The statistics revealed that the mean pretest scores of the EG were 74.45 and 72.11 for the CG. The mean scores of both groups enhanced after they received the treatments. The mean posttest score for the EG was 86.81, whereas the CG scored 81.05. After examining the data, it was discovered that there were discrepancies in scores between students taught using the Kahoot game and those taught utilizing the traditional technique.

Kaur [4] described the results of a short survey of 50 secondary school students at an international school who used Kahoot to learn a new language. There were ten questions on a five-point Likert scale in the research. Nearly every respondent reported having a favorable experience when their classes included Kahoot. The Kahoot platform, according to the majority of learners, allowed them to participate actively in their language classes. According to the vast majority of participants, using Kahoot in language courses was a success. A more relevant and rich language learning experience is provided by adaptive software and platforms like Kahoot, which encourage learners to participate in their language learning processes.

Wang and Tahir [14] published a study that presented the findings of a literature review on the impact of utilizing Kahoot for learning, significantly how Kahoot impacts learning performance, classroom dynamics, learners' and instructors' attitudes and views, and students' anxiety. The evaluation covered 93 papers, and the significant finding was that Kahoot might improve learning performance, classroom dynamics, learners' and instructors' perspectives, and students' anxiety. However, studies have shown that Kahoot has little or no impact. Participants' significant challenges involve technical issues such as unverified Internet connections, difficulty reading responses to questions on a projected screen, inability to change answers after submission, stressful time-pressure for providing solutions, insufficient time to respond, fear of losing, and difficulty catching up if an incorrect response was provided. Furthermore, the main challenges noted by educators involve getting the level of difficulty of questions and answers accurate, network connectivity issues, scoring based on how quickly understudies reply, lessening student reflection, and causing some understudies to assume without thinking that some understudies may have a challenge failing a quiz and that some instructors may find it really difficult to use the technology.

Quiroz et al. [48] used a quasiexperimental posttest method to investigate the impact of Kahoot on increasing English vocabulary acquisition in an EFL environment. The research comprised an EG and a CG from two 9th grade courses. The pre- and posttests were given to both groups, and the results were compared to see whether there was any variance. The interventions in each group lasted four weeks and consisted of two lessons each week. The experimental treatment findings, in particular, demonstrated an increase in English vocabulary knowledge utilizing the Kahoot program, with a substantial variance and a medium impact size.

Hussein and Alshra'ah [49] evaluated the impact of Kahoot on the development of EFL Saudi learners' vocabulary learning, reading comprehension, and attitudes about the game, as well as their opinions toward it. A sample of 77 male EFL Saudi students at Imam Mohamed Ibn Saud Islamic University's Deanship of Preparatory Programs was used to attain this goal, and the researchers used an experimental technique to accomplish their goal. To achieve this, the researchers purposely selected two scientific stream courses, with one class consisting of 38 participants being allocated as an EG and the other class comprising 39 participants being allocated as a CG. The conventional approach was utilized in the first term of the academic year to educate the CG, while Kahoot was used in the second term to educate the experimental technique (2018-2019). Specifically, three instruments were employed in the present investigation: a vocabulary test, a reading comprehension exam, and a questionnaire. Participants' postvocabulary acquisition and reading comprehension examinations revealed statistically significant differences between the means of the two groups, indicating that the EG outperformed the other group on both exams. This might be attributable to the fact that Kahoot was used. This suggested that using Kahoot as an educational technique had a favorable impact on improving students' vocabulary learning and reading comprehension skills.

In conclusion, compared to conventional learning methods and other learning aids, the Kahoot may have a good impact on learning in various situations and domains. Several articles have written about the effects of the Kahoot platform and indicated the positive impact of this game on learning English language development. Yet, the effects of Kahoot have not been broadly examined on Iranian EFL learners' vocabulary recall and retention. Therefore, this study tried to examine the effects of the Kahoot game on Iranian EFL learners' vocabulary learning, hoping that the results of this study contribute to the related literature and encourage teachers and material developers to integrate the game-based instruments in their classes and syllabuses.

Based on the goal of the research, two questions were posed:

RQ1: does using Kahoot as a game-based learning tool significantly develops Iranian EFL learners' vocabulary recall?

RQ2: does using Kahoot as a game-based learning tool significantly develops Iranian EFL learners' vocabulary retention?

\section{Method}

3.1. Participants. Research participants were 50 intermediate learners who were selected from a pool of 78 learners at the Pars English Language Institute in Ahvaz, in the Iranian 
province of Khuzestan. All of these pupils were male, ranging from 16 to 33 years old. According to their performance on the Oxford Quick Placement Test, their level of English language competence was evaluated (OQPT). In this study, the respondents were recruited using a convenience sample strategy, which means that only those easily available learners were chosen to participate in the research. The students were separated into two groups of 25 each, which were designated as EG and CG.

3.2. Instruments. A proficiency exam entitled the Oxford Quick Placement Test (OQPT) was used in the present investigation to homogenize the respondents. All of the respondents completed this test to ensure that they were all of the same levels of competence. It aided the researcher in selecting intermediate pupils; those who scored between 40 and 47 were classified as being at the intermediate level of learning.

Using the participants' coursebook as a guide, a researcher-created vocabulary pretest was used to collect information for this study's second and most crucial tool, which was used to address the question asked in the first. It consisted of 30 multiple-choice questions. For the test to be valid and reliable, it was piloted on a comparable group of people who were not included in either the experimental or control groups. The purpose of this piloting was to determine the time of the test and the item difficulty and item discrimination, as well as to calculate the dependability of the tests. Learners would have enough time to complete the exam; it was predicted that they would have 30 minutes to complete the test. The time taken by the quickest learner and the time taken by the slowest learner were combined by the researcher to determine the overall time. The mean was then determined in order to determine the actual time required by the students to complete the assessments. In order to arrive at this time, the quickest student added the time used by the slowest learner to arrive at a total time of two minutes.

According to Hatch and Farhady [50], the degree to which a test gives consistent findings when conducted under identical settings is known as the dependability of the test. Consequently, consistency of results is the most fundamental idea in the dependability of a testing procedure. When the vocabulary pretest was conducted on one pilot group, it was possible to determine its reliability. The vocabulary exam was piloted on 15 intermediate students comparable to the experimental and CG learners in terms of ability. It was determined that the test was reliable by calculating the reliability coefficient (K-R 21 formula), which came out to be 0.82 . In contrast to the reliability, which is a strictly statistical measure, validity is a question of degree that is significantly influenced by the specifics of the test being administered. A team of English language specialists evaluated and verified the exam.

This research employed three instruments, the third of which was an instant vocabulary posttest. The study's posttest consisted of a modified version of the pretest that had been previously administered. All of the parameters of the posttest, including the kind of questions and the number of items, were the same as those of the pretest. The only distinction between this exam and the pretest was that the sequence of the questions and options were switched to eliminate the possibility of recalling the responses from the pretest. It was given to the students to assist the researchers in determining the efficiency of the therapy on their vocabulary acquisition. Because the posttest was the same as the pretest, all participants deemed it valid and trustworthy (the reliability and validity of the pretest are reported above). It should be noted that this test was used both as the immediate posttest and the delayed posttest.

3.3. Materials (Target Words). The respondents were provided with a list of new words from their textbook (504 Essential Vocabulary). Based on the assumptions of Dufon and Fong [51], the target words which will be taught would be unknown, unfamiliar, or difficult for the participants, so the researchers selected the target words out of the mentioned reading texts. The participants' degree of familiarity with the target items was realized through a vocabulary list. In other words, a list of 130 words was prepared by the researchers, and it was given to the students to determine their familiarity with the terms. If a comment was known to the majority of the participants, then it was excluded from the study. After answering this list, it was revealed that 80 words were unfamiliar and unknown for the students, and they were regarded as the target words.

3.4. Procedures. As a first stage, 50 Iranian EFL learners were recruited and randomly split into two equal groups: one for the EG and another for the CG. Then, they were subjected to a pretest consisting of a vocabulary exam created by the researcher, and the therapy was practiced on them. As the treatment, the researcher taught 80 vocabulary items to the EG by applying the Kahoot game. All students had access to Kahoot and then entered the game PIN. One new vocabulary was displayed on the screen. Its meaning was provided for the students in a multiple-choice format. Four different meanings were provided, and the students were required to guess and select the right option. This procedure continued to teach ten words in each session. In fact, in each session, the students responded to ten vocabulary multiple-choice questions by clicking the options they had taught were correct. When all students answered and selected their options, the results of the quiz were shown to see who had the highest score and was the winner of the game. This procedure continued to teach 80 vocabularies to the EG. The CG received traditional vocabulary instruction. The meanings of 80 words were provided for them in a printed format, and the words were used in new sentences to help them learn the meanings more deeply. In each session, ten vocabulary items were trained for this group. The researcher provided the Persian equivalent of each word; in addition, he provided English antonyms for the majority of the new words. At the beginning of each session, a vocabulary quiz was administered to the students. After teaching all 80 vocabulary items, both groups took the immediate vocabulary posttest, and three weeks later, a delayed vocabulary posttest was 
TABLE 1: Means and standard deviations of both groups on the vocabulary pretest.

\begin{tabular}{lcccc}
\hline Groups & $N$ & Means & Std. deviations & Std. error means \\
\hline CG & 25 & 12.76 & 2.12 & 0.42 \\
EG & 25 & 13.48 & 2.43 & 0.48 \\
\hline
\end{tabular}

TABLE 2: Inferential statistics of both groups on the vocabulary pretest.

\begin{tabular}{|c|c|c|c|c|c|c|c|c|}
\hline & & \multicolumn{2}{|c|}{$\begin{array}{l}\text { Levene's } \\
\text { test for } \\
\text { equality of } \\
\text { variances }\end{array}$} & \multirow[b]{2}{*}{$\mathrm{t}$} & \multirow[b]{2}{*}{$\mathrm{df}$} & \multicolumn{2}{|c|}{$t$-test for equality of means } & \multirow[b]{2}{*}{ Std. error difference } \\
\hline & & $\mathrm{F}$ & Sig. & & & Sig. (2-tailed) & Mean difference & \\
\hline Scores & $\begin{array}{c}\text { Equal variances assumed } \\
\text { Equal variances not assumed }\end{array}$ & 0.29 & 0.59 & $\begin{array}{l}1.11 \\
1.11\end{array}$ & $\begin{array}{c}48 \\
47.15\end{array}$ & $\begin{array}{l}0.27 \\
0.27\end{array}$ & $\begin{array}{l}-0.72 \\
-0.72\end{array}$ & $\begin{array}{l}0.64 \\
0.64\end{array}$ \\
\hline
\end{tabular}

TABLE 3: Means and standard deviations of both groups on the immediate vocabulary posttest.

\begin{tabular}{lcccc}
\hline Groups & $N$ & Means & Std. deviations & Std. error means \\
\hline CG & 25 & 13.84 & 2.30 & 0.46 \\
EG & 25 & 18.12 & 1.98 & 0.39 \\
\hline
\end{tabular}

TABLE 4: Inferential statistics of both groups on the immediate vocabulary posttests.

\begin{tabular}{|c|c|c|c|c|c|c|c|c|}
\hline & & \multicolumn{2}{|c|}{$\begin{array}{l}\text { Levene's } \\
\text { test for } \\
\text { equality of } \\
\text { variances }\end{array}$} & \multirow[b]{2}{*}{$\mathrm{t}$} & \multirow[b]{2}{*}{ Df } & \multicolumn{2}{|c|}{$t$-test for equality of means } & \multirow[b]{2}{*}{ Std. error difference } \\
\hline & & $\mathrm{F}$ & Sig. & & & Sig. (2-tailed) & Mean difference & \\
\hline Scores & $\begin{array}{c}\text { Equal variances assumed } \\
\text { Equal variances not assumed }\end{array}$ & 0.74 & 0.39 & $\begin{array}{l}7.03 \\
7.03\end{array}$ & $\begin{array}{c}48 \\
46.97\end{array}$ & $\begin{array}{l}0.00 \\
0.00\end{array}$ & $\begin{array}{l}-4.28 \\
-4.28\end{array}$ & $\begin{array}{l}0.60 \\
0.60\end{array}$ \\
\hline
\end{tabular}

TABLE 5: Means and standard deviations of both groups on the delayed vocabulary posttest.

\begin{tabular}{lccccc}
\hline & Groups & $N$ & Mean & Std. deviation & Std. error mean \\
\hline \multirow{2}{*}{ Scores } & CG & 25 & 14.40 & 2.64 & 0.52 \\
& EG & 25 & 17.68 & 1.86 & 0.37 \\
\hline
\end{tabular}

administered to the participants of both groups to examine the effectiveness of the treatment on their vocabulary retention.

3.5. Data Analysis. Data analysis was done using the SPSS software version 22 to respond to the research question. In the first instance, descriptive statistics such as the means and standard deviations were computed. Three independent samples $t$-tests were employed to investigate the effects of the therapy on Iranian EFL learners' vocabulary knowledge in the second phase of the study.

\section{Results}

The gained results are presented in the following tables.

The descriptive data for both groups before the test are shown in Table 1. The mean score for the CG is 12.76, while the mean score for the EG is 13.48. Essentially, this suggests that both groups had the same level of vocabulary knowledge before undergoing the intervention. An independent samples $t$-test was used in Table 2 to see if the differences between the two groups were significant or not.

To determine whether there is a statistically significant difference between the vocabulary pretests of the two groups, an independent samples $t$-test was performed in Table 2 . Given that Sig. (0.27) is more than 0.05, the difference between the pretests of both groups is not statistically significant at $p>0.05$, according to the findings. Based on the results, one can conclude that both EG and CG had the same vocabulary knowledge before carrying out the game-based instruction.

The descriptive statistics of both groups' performance on the vocabulary posttest are shown in Table 3. The typical score for the CG is 13.84, whereas the mean score for the EG 
TABLE 6: Inferential statistics of both groups on the delayed vocabulary posttests.

\begin{tabular}{|c|c|c|c|c|c|c|c|c|}
\hline & & \multicolumn{2}{|c|}{$\begin{array}{l}\text { Levene's } \\
\text { test for } \\
\text { equality of } \\
\text { variances }\end{array}$} & \multirow[b]{2}{*}{$t$} & \multirow[b]{2}{*}{ df } & \multicolumn{2}{|c|}{$t$-test for equality of means } & \multirow[b]{2}{*}{ Std. error difference } \\
\hline & & $\mathrm{F}$ & Sig. & & & Sig. (2-tailed) & Mean difference & \\
\hline \multirow[t]{2}{*}{ Scores } & Equal variances assumed & 2.82 & 0.09 & 5.06 & 48 & 0.00 & 3.28 & 0.64 \\
\hline & Equal variances not assumed & & & 5.06 & 43.12 & 0.00 & 3.28 & 0.64 \\
\hline
\end{tabular}

is 18.12. It is necessary to conduct an independent samples $t$ test to determine whether the difference between the posttests of the groups is statistically significant (see Table 4).

Table 4 demonstrates that the difference between the two groups is statistically significant $(p<0.05)$. Based on the results, the Sig. value $(0.00)$ is less than 0.05 , implying that the performances of both groups were different on the vocabulary posttest. When it came to the vocabulary posttest, the EG performed much better than the CG. This improvement may be ascribed to the game-based teaching that was implemented.

Based on the delayed posttest descriptive statistics in Table 5, the mean score of the CG is 14.40, and the mean score of the EG is 17.68. It is apparent that the EG group got better scores on the delayed vocabulary posttest. An independent samples $t$-test should be applied to discover any significant difference between the delayed posttests of both groups (see Table 6).

Based on Table 6, the difference between the delayed posttests of both groups is significant as the Sig. value (0.00) is less than 0.05 . The experimental participants outflanked the control participants on the delayed vocabulary posttest thanks to receiving a game-based instruction. We can say that applying Kahoot as a game-based instrument is a reason why the EG group outperformed the CG on the delayed vocabulary posttest.

\section{Discussion and Conclusion}

Based on the outcomes of the current study, both EG and CG got the same scores on the pretest while they had different performances on the vocabulary posttests. In fact, the EG who received the instruction through the Kahoot game outperformed the CG on the immediate and delayed posttests. Therefore, the null hypothesis of the study "using Kahoot as a game-based learning tool does not develop Iranian EFL learners' vocabulary recall and retention significantly" is rejected.

The findings of this study are supported by Boulaid and Moubtassime [17], who examined the effects of using Kahoot on enhancing the English vocabulary of Moroccan EFL University students. Their results revealed that using Kahoot significantly contributed to students' vocabulary development. Our findings also offer credence to the findings of Putri [47], who investigated the usefulness of a Kahoot game on enhancing students' vocabulary understanding and discovered that those students who were taught via Kahoot outperformed the control group on a vocabulary posttest.
The outcomes of this research are consistent with the results of Ciaramella [52], who assessed the influence of Kahoot on vocabulary acquisition and retention and found that utilizing a game-based learning platform increased vocabulary acquisition and retention. The outcomes of this research are in line with the findings of Taheri [53], who explored the influence of language games on primary children's vocabulary memory. The data analysis demonstrated that the influence of game-like activities was more substantial in the delayed period than in the immediate moment. In addition, Wang [40] confirmed our result since they suggested that Kahoot created a positive learning experience and encouraged their participation. The outcomes of this research corroborate the results of Bartsch and Murphy [54], who verified the effectiveness of games on language learning. In addition, $\mathrm{Li}$ [55] advocated our results, whose study indicated that game-based vocabulary learning developed students' vocabulary knowledge, self-confidence, and motivation.

Games are fantastic educational tools that can be used in all courses to gain the learners' attention, increase interaction, and review the subject matter. However, game-based response systems allow the learners to respond to questions displayed on a screen in classes. The learners click their answers on multiple chosen questions using mobile devices, primarily mobile phones. The answers to the questions are immediately shown to the class visually. The mentioned advantages for the game-based learning can be the reasons why the EG outflanked the CG on the posttest.

According to this research, when learners participate in a vocabulary game, they have reciprocal orientations toward achieving a goal, which is to locate the new word and vanquish the other group. In reality, they are intuitively compelled to cooperate and consult (talk to one other and use terminology and phrases) to defeat the opposing group. Even weak students participate in the activity since there is no need for them to be concerned about their marks, and the instructor just observes the pupils and declares the winners and losers. In a vocabulary game, learners' efforts to obtain the best response involve them in social interaction. Learners are relieved of the anxious constraints of being monitored when they participate in vocabulary game-like exercises, which improves their capacity to acquire and retain vocabulary items. Learners in groups strive to find unfamiliar vocabulary items by bargaining with one another, enhancing student collaboration. Constructivist theorists, who think that social interactions are essential for learning, highly admire our research findings. 
This study examined the effectiveness of using gamebased instruction (Kahoot) on Iranian EFL learners' vocabulary learning. As previously mentioned, the findings indicated that using Kahoot was fruitful and advantageous for learning English vocabulary. The overall outcomes of this research highlight the usefulness of using Kahoot to acquire vocabulary as an alternative to more traditional resources and the relative advantages of integrating Kahoot in collaborative learning activities in classroom settings. Because the impact of employing game-based education on vocabulary acquisition has been shown to be favorable and substantial, game-based instruction should be prioritized in any language program more than ever.

Fun, pleasure, and high motivation levels may be achieved by using games in the classroom. In addition, games play an essential role in reducing the fear of speaking the target language. Playing games is a necessary part of learning a language since it allows students to have fun while simultaneously getting practice in the target language. Playing games may be considered an excellent way to teach vocabulary because of its usefulness and effectiveness as an educational tool. Teachers of English as a second language (EFL) may improve their students' learning experience by using games in their classes. The results of this research show that games are essential teaching tools in language classes because they create a relaxed atmosphere for students and are beneficial to both students and instructors when they have an educational goal rather than just being entertaining.

Students, educators, and material creators may benefit from the outcomes of this research. Teachers might suggest to their pupils that they acquire language by playing games. Instructional games are essential for instructors of all ages, including preschoolers, elementary school students, and adult learners. Instructors may employ activities to encourage students to work together and expose them to the interactive use of vocabulary, such as testing one other on new terms and debating word definitions in conversation. Learning vocabulary via games can and should be utilized to provide collaborative learning opportunities for lexical growth both in and out of the classroom. Via using games, teachers can have more relaxing and amusing classes. In addition, using games in EFL classes can help teachers create more meaningful contexts for teaching and learning the English language. Teachers can use games in their classes to make students involved and interested in language learning and persuade them to use games out of the classrooms.

Students of English as a foreign language may benefit from this research. Games have a massive impact on students, and this is one of its most significant advantages. Memory, association, linguistic, cognitive, interpersonal, arithmetic, listening, and more are some of the skills students develop via games. As simple, adaptable, and underutilized tool for instructing young students, games may be a powerful teaching tool. A teacher may utilize their imagination and adapt diverse subjects in graphics to teach vocabulary at a cheap cost and with recyclable value because of this variety in the materials used. Students may acquire vocabulary and enhance their English abilities via games. EFL students may utilize games to acquire and link new
English terms with their current understanding of English vocabulary. Students may carry their education around with them wherever they go because of games' convenience. Instructional games enable students to acquire vocabulary on their mobile devices at any time and in any location. By using games in their learning, students can increase their learning motivation, reduce their learning stress, and develop their authentic communications [56]. Since students encounter unknown vocabularies, grammatical points, texts, etc., they may feel a high level of anxiety in the classes, which can certainly affect their learning capability. As a result, using games can assist to reduce their anxiety, make them feel comfortable, and want to learn more.

It is important to note that the outcomes of this research have significant implications for ELT curriculum developers who build courses for L2/FL learners of various abilities. Course designers are encouraged to include communicative activities like games into their lessons for language learners so that the students may benefit from them. Teachers need to keep in mind how much work the children will have to put into the games they choose. Further implications for the Iranian Ministry of Education are significant since the ministry has traditionally relied on conventional language education techniques to develop its curriculum and textbooks. Using communicative activities like games to boost student motivation and language acquisition is something that the Ministry of Education should consider.

The findings of this research may encourage ESL and native researchers to do more empirical studies on the effectiveness of different kinds of instructional games on learning English and other subjects such as math, art, and geography.

It is possible that a number of limitations impacted the results of this research. The number of participants was restricted to 50 . More than 50 participants in this study will need to be included if present research findings are confirmed in a bigger sample size. This research was conducted at a single university in a city in the south of Iran. As a result, the results cannot be generalized to other districts in Iran since one district may not be representative.

Further research may be carried out in different parts of Iran to assess the impact of game-based training on various English abilities and subcompetencies; because the study only included people aged 16 to 33 , its findings cannot be applied to other age groups. Different age groups should be the focus of future research. Only pre- and posttests were utilized to gather data in this research; qualitative instruments like interviews are advised for future studies to get more reliable data.

\section{Data Availability}

The underlying data supporting the results of this study can be found by direct contact with the corresponding author upon reasonable request.

\section{Conflicts of Interest}

The authors declare that there are no conflicts of interest. 


\section{References}

[1] R. Dellos, "Kahoot: a digital game resource for learning," International Journal of Instructional Technology and Distance Learning, vol. 12, no. 4, pp. 49-52, 2015.

[2] M. S. Ab Yajid and S. M. Ferdous Azam, "Role of web search engines in knowledge acquisition," Systematic Reviews in Pharmacy, vol. 11, no. 1, pp. 742-751, 2020.

[3] D. Tan Ai Lin, M. Ganapathy, and M. Kaur, "Kahoot! It: gamification in higher education," Pertanika Journal of Social Sciences \& Humanities, vol. 26, no. 1, pp. 67-79, 2018.

[4] P. Kaur, "Kahoot in the English language classroom," South East Asia Journal of Contemporary Business, Economics and Law, vol. 20, no. 2, pp. 49-54, 2020.

[5] K. Seneviratne, J. A. Hamid, A. Khatibi, F. Azam, and S. Sudasinghe, "Multi-faceted professional development designs for science teachers' self-efficacy for inquiry-based teaching: a critical review," Universal Journal of Educational Research, vol. 7, no. 7, pp. 1595-1611, 2019.

[6] J. Hadfield, A Collection of Games and Activities for Low to Mid- Intermediate Students of English Intermediate Communication Games, Thomus and Nelson and Sons Ltd, Scotland, 2003.

[7] M. N. Gömleksiz, "Newly developed 5th grade science and technology course curriculum," International Journal of Education, vol. 6, pp. 11-41, 2008.

[8] A. Gunasinghe, J. A. Hamid, A. Khatibi, and S. M. Azam, "Does the lecturer's innovativeness drive VLE adoption in higher education institutes? (A study based on extended UTAUT)," Journal of Information Technology Management, vol. 10, no. 3, pp. 20-42, 2018.

[9] Y. Kartal, "The EAGLE project: simulating the evolution and assembly of galaxies and their environments," Monthly Notices of the Royal Astronomical Society, vol. 46, no. 1, pp. 521-554, 2014.

[10] S. Smith-Robbins, "This game sucks: how to improve the gamification of education," Educause Review, vol. 46, no. 1, pp. 58-59, 2011.

[11] S.-F. Tong, N. Mohamad, C.-E. Tan, B. Efendie, K. K. Chelliah, and J. H. Gilbert, "Transition from uniprofessional towards interprofessional education: the Malaysian experience of a pragmatic model," in Leading Research and Evaluation in Interprofessional Education and Collaborative Practice, pp. 169-192, Palgrave Macmillan, London, UK, 2016.

[12] X. Qu, "Hybrid game-based learning research at English class of primary school," OALib, vol. 08, no. 12, pp. 1-6, 2021.

[13] A. I. Wang, T. Ofsdal, and O. K. Morch-Storstein, "Lecture quiz- a mobile game concept for lectures," in Proceedings of the IASTED International Conference on Software Engineering and Application (SEA 2007), Acta Press, Cambridge, MA, USA, 2007.

[14] A. I. Wang and R. Tahir, "The effect of using Kahoot! for learning- A literature review," Computers and Education, vol. 149, no. 2, Article ID 103818, 2020.

[15] A. R. Alsoud and A. A. Harasis, "The impact of COVID-19 pandemic on student's E-learning experience in Jordan," Journal of Theoretical and Applied Electronic Commerce Research, vol. 16, no. 5, pp. 1404-1414, 2021.

[16] N. Ç. Aktekin, H. Çelebi, and M. Aktekin, "Let's Kahoot! Anatomy," International Journal of Morphology, vol. 36, no. 2, pp. 716-721, 2018.

[17] F. Boulaid and M. Moubtassime, "Investigating the role of Kahoot in the enhancement of English vocabulary among Moroccan university students: English department as a case study," International Journal of Innovation and Applied Studies, vol. 27, no. 3, pp. 797-808, 2019.

[18] D. G. Oblinger and J. L. Oblinger, "Educating the net generation," International Journal of Evaluation and Research in Education, vol. 4, no. 1, pp. 39-47, 2017.

[19] R. Oktaviati and A. A. Jaharadak, "The impact of using gamification in learning computer science for students in university," International Journal of Engineering and Technology, vol. 7, no. 4, pp. 121-125, 2018.

[20] N. Schmitt and R. Carter, "The lexical advantages of narrow reading for second language learners," TESOL Journal, vol. 9, no. 1, pp. 4-9, 2000.

[21] N. Schmitt, "Review article: instructed second language vocabulary learning," Language Teaching Research, vol. 12, no. 3, pp. 329-363, 2008.

[22] M. Macis and N. Schmitt, "Not just 'small potatoes': knowledge of the idiomatic meanings of collocations," Language Teaching Research, vol. 21, no. 3, pp. 321-340, 2017.

[23] S. V. Vadivu and S. Chupradit, "Psychosocial and occupational impact assessment due to internet addiction: a critical review," Syst Rev Pham, vol. 11, pp. 152-155, 2020.

[24] M. A. A. Adam, Role of Vocabulary Learning Strategies in Promoting EFL Learners' Performance, Sudan University of Science and Technology, Khartoum, Sudan, 2016.

[25] L. Sheldon, Multiplayer Classroom: Designing Coursework as a Game, Cengage Learning, Boston, MA,USA, 2011.

[26] M. D. Dickey, "Engaging by design: how engagement strategies in popular computer and video games can inform instructional design," Educational Technology Research \& Development, vol. 53, no. 2, pp. 67-83, 2005.

[27] S. Deterding, M. Sicart, L. Nacke, K. O’Hara, and D. Dixon, "Gamification: using game-design elements in nongaming contexts," in CHI '11 Extended Abstracts On Human Factors In Computing Systems (CHI EA '11), pp. 2425-2428, ACM, New York, USA, 2011.

[28] R. M. Ryan and E. L. Deci, "Self-determination theory and the facilitation of intrinsic motivation, social development, and well-being," American Psychologist, vol. 55, no. 1, pp. 68-78, 2000.

[29] C. I. Muntean, "Raising engagement in e-learning through gamification," in Proceedings of the 6th International Conference On Virtual Learning ICVL, pp. 323-329, Cluj-Napoca, Romania, Europe, 2011.

[30] J. L. Plass, B. D. Homer, and C. K. Kinzer, "Foundations of game-based learning," Educational Psychologist, vol. 50, no. 4, pp. 258-283, 2015.

[31] A. Bandura, "Social cognitive theory: an agentic perspective," Annual Review of Psychology, vol. 52, no. 1, pp. 1-26, 2001.

[32] A. J. Elliot and H. A. McGregor, "A $2 \times 2$ achievement goal framework," Journal of Personality and Social Psychology, vol. 80, no. 3, pp. 501-519, 2001.

[33] L. Vygotsky, Mind in Society. The Development of Higher Psychological Processes, Harvard University Press, Cambridge, MA, USA, 1978.

[34] J. Lave and E. Wenger, Situated Learning: Legitimate Peripheral Participation, Cambridge University Press, USA, 1991.

[35] J. E. Caldwell, "Clickers in the large classroom: current research and best-practice tips," CBE-life Sciences Education, vol. 6, no. 1, pp. 9-20, 2007.

[36] R. H. Kay and A. LeSage, "Examining the benefits and challenges of using audience response systems: a review of the literature," Computers \& Education, vol. 53, no. 3, pp. 819-827, 2009. 
[37] S. Chupradit, A. Leewattana, and P. W. Chupradit, "The correlation analysis of Internet usage and depression among undergraduate university students in Thailand: cross-sectional study," Journal of Advanced Research in Dynamical \& Control Systems, vol. 12, pp. 825-837, 2020.

[38] R. Lacey, "Richer responses, faster feedback in class: new student response systems promote personalization and largegroup discussions," District Administration, vol. 52, no. 11, pp. 10-24, 2016.

[39] M. Qian and K. R. Clark, "Game-based Learning and 21st century skills: a review of recent research," Computers in Human Behavior, vol. 63, pp. 50-58, 2016.

[40] A. I. Wang, "The wear out effect of a game-based student response system," Computers \& Education, vol. 82, pp. 217-227, 2015.

[41] E. P. Zhelyazova, "Vocabulary perceptions and principles in foreign language learning and teaching," Scientific University of Rousse, vol. 50, no. 6.3, pp. 145-154, 2011.

[42] N. T. T. Huyen, "Learning vocabulary through games," Asian EFL Journal, vol. 3, pp. 77-89, 2003.

[43] E. Jaaska and K. Aaltonen, "Teachers' experiences of using game-based learning methods in project management higher education," Project Leadership and Society, vol. 3, pp. 1-12, 2022.

[44] M. W. Barbosa and C. de Ávila Rodrigues, "Project portfolio management teaching: contributions of a gamified approach," International Journal of Management in Education, vol. 18, no. 2, Article ID 100388, 2020.

[45] J. R. Drake, "A critical analysis of active learning and an alternative pedagogical framework for introductory information systems courses," Journal of Information Technology Education: Innovations in Practice, vol. 11, pp. 1-14, 2012.

[46] E. Akdogan, "Developing vocabulary in game activities and game materials," Journal of Teaching and Education, vol. 7, no. 1, pp. 31-64, 2017.

[47] A. R. Putri, "The effectiveness of using Kahoot game to improve students' vocabulary comprehension a quasi-experimental research of seventh grade students of SMP n 15 SEMARANG in the academic year of 2019/2020," Under Graduates thesis, UNNES, Semarang, Indonesia, 2019.

[48] M. Quiroz, R. Gutiérrez, F. Rocha, M. Valenzuela, and C. Vilches, "Improving English vocabulary learning through Kahoot: a quasi-experimental high school experience," Teaching English with Technology, vol. 21, no. 2, pp. 3-13, 2021.

[49] M. Hussein and A. Alshra'ah, "The effect of Kahoot on developing EFL Saudi students' vocabulary acquisition, reading comprehension, and their attitudes towards such a strategy," Journal of the Islamic University of Educational and Psychological Studies, vol. 29, no. 1, pp. 604-619, 2021.

[50] e. Hatch and H. Farhady, Research Design and Statistics for Applied Linguistics, Rowley, Newburry, England, 1981.

[51] P. Dufon and C. H. Fong, "L1 and L2 vocabulary glosses in L2 reading passages: their effectiveness for increasing comprehension and vocabulary knowledge," Journal of Research in Reading, vol. 17, no. 1, pp. 19-28, 1994.

[52] K. E. Ciaramella, "The effects of Kahoot on vocabulary acquisition and retention of students with learning disabilities and other health impairments," A thesis, Department of Interdisciplinary and Inclusive Education College of Education in Partial Fulfillment of the Requirement for the Degree of Master of Arts in Special Education: Rowan University, Glassboro, NJ, USA, 2018.
[53] M. Taheri, "The effect of using language games on vocabulary retention of Iranian elementary EFL learners," Journal of Language Teaching and Research, vol. 5, no. 3, pp. 544-549, 2014.

[54] R. A. Bartsch and W. Murphy, "Examining the effects of an electronic classroom response system on student engagement and performance," Journal of Educational Computing Research, vol. 44, no. 1, pp. 25-33, 2011.

[55] R. Li, "Does game-based vocabulary learning APP influence Chinese EFL learners'vocabulary achievement, motivation, and self-confidence?" Sage Open, vol. 2, pp. 1-12, 2021.

[56] M. Sailer and L. Homner, "The gamification of learning: a meta-analysis," Educational Psychology Review, vol. 32, no. 1, pp. 77-112, 2020. 